The final, published version of this article is available online. Please check the final publication record for the latest revisions to this article.

Agić, H. (2016). A new species of small acritarch with a porous wall structure from the early Cambrian of Estonia and implications for the fossil record of eukaryotic picoplankton. Palynology, 40(3): 343-356. DOI: 10.1080/01916122.2015.1068879. 


\title{
A new species of small acritarch with porous wall structure from the early Cambrian of Estonia and implications for the fossil record of eukaryotic picoplankton
}

\author{
Heda Agić \\ Uppsala University, Department of Earth Sciences, Palaeobiology, Villavägen 16, 75236 \\ Uppsala, Sweden. Email: heda.agic@geo.uu.se
}

\begin{abstract}
The Proterozoic-Phanerozoic transition records a general trend of decrease in the phytoplankton cell size, in contrast to the earlier and much larger Ediacaran acritarchs. Particularly minute, unornamented, but sculptured organic-walled microfossils have been recovered from the lower Cambrian Lükati Formation in northern Estonia. Lack of any significant thermal alteration in the formation allowed for excellent preservation of fine microstructures on these microfossils. Among the rich palynomorph assemblage in Lükati, a new species of tiny, spheroidal eukaryotic microfossil is recorded: Reticella corrugata gen. et sp. nov. It is characterized by a corrugated and flexible vesicle wall that is densely perforated by nano-scale pores. Despite its unique morphology, the new species shares diagnostic characters with fossil and extant prasinophyte algae. R. corrugata is among the smallest microfossils with typical eukaryotic morphology (conspicuous wall sculpture) and contributes to the diversity of the size-class of small acritarchs. Size, abundance, inferred prasinophyte affinity, and eukaryotic wall sculpture make this new taxon a likely member of the early eukaryotic picoplankton.
\end{abstract}

Keywords: Cambrian, Estonia, organic-walled microfossils, picoplankton, prasinophytes, small acritarchs

\section{Introduction}

Eukaryotic picoplankton provides a significant contribution to the overall primary productivity (up to $90 \%$ ), biomass (over $70 \%$ of chlorophyll) and genetic diversity of phytoplankton in present day marine environments (Joint 1987; Stockner 1988; Lewin et al. 2000; Foulon et al. 2008). Despite such ecological importance, the taxonomy and 
evolutionary history of the group are little understood. Modern picoplankton is an ecological size category that includes phototrophic prokaryotes and eukaryotes $0.1-5 \mu \mathrm{m}$ in diameter, widely distributed in both marine and freshwater systems (Lewin et al. 2000).

A large number of known taxa comprising eukaryotic picoplankton belong to the class Prasinophyceae (Chlorophyta) (Meakin \& Wyman 2011; Leliaert et al. 2012). This group also includes the smallest living eukaryote - Ostreococcus tauri (Courties et al. 1994). The evolutionary history of prasinophytes is well recorded from the Proterozoic to present (Boalch \& Parke 1971; Guy-Ohlson 1996, Playford 2003; Schrank 2003; Moczydłowska et al. 2011; Knoll 2014), thanks to the resilient and readily preservable outer cyst walls (phycomata) (Talyzina \& Moczydłowska 2000; Leliaert et al. 2012).

In contrast, the fossil record of the picoplankton has not been studied as comprehensively, mostly because such cells are difficult to observe with light microscopy or they may be lost through the usual palynological preparation techniques. However, minute organic-walled microfossils have been reported throughout Phanerozoic. Habib \& Knapp (1982) coined the term "small acritarchs" for unicellular organic-walled microfossils generally smaller than $10 \mu \mathrm{m}$, mainly abundant in Mesozoic and Cenozoic successions, but these small forms range from the Cambrian to the Neogene (Downie 1973; Tappan 1980; Moczydłowska 1991; 2011; Schrank 2003).

Such minute sphaeromorphs, ca. $7 \mu \mathrm{m}$ in diameter, with nano-scale pores are described herein from the lower Cambrian Lükati Formation exposed in the Kopli Quarry in northeastern Estonia. Among the earliest occurrences of the size-class of "small acritarchs," this record shines a new light on the evolution and antiquity of this group of microfossils and potentially the early occurrence of eukaryotic picoplankton.

Other prominent taxa in the Lükati Formation include the prasinophytes Tasmanites, Pterospermella and Cymatiosphaera, and the chlorophytes Asteridium, Heliosphaeridium, Comasphaeridium, Globosphaeridum, and Skiagia, which have evolved or additionally diversified during this time interval (Moczydłowska 1991, 2011). This fossil assemblage is common in early Cambrian age deposits worldwide (e.g. Moczydłowska 2011; Palacios et al. 2011). The Lükati Formation record is enriched by the presence of small microfossils of Reticella corrugata gen. et sp. nov. (Plates 1,2). This new taxon is exceptional by its minuscule dimensions, pristine fine surface sculpture and porous wall, that is observable mainly with scanning electron microscopy. However, despite its uniqueness, there are similarities of individual morphological elements to certain taxa of various ages (Proterozoic 
to Recent), which are both small and large in the size-scale of microfossils (four to hundreds $\mu \mathrm{m})$.

Reticella gen. nov. is interpreted in terms of its biological affinity, significance of phytoplankton radiation, and diversity in the early Cambrian, and similarity to microfossil body plans that have already appeared earlier in the Proterozoic (e.g. Cerebrosphaera-like corrugated sphaeromorphs).

\section{Geological Setting}

The Lükati Formation, exposed in the northern Estonia (Figure 1), is part of the Baltic Syncline and derives from the lower Cambrian stratigraphic interval extending over the East European Platform. It is a siliciclastic succession that was deposited in a shallow marine environment (up to $100 \mathrm{~m}$ in depth) at the western margin of the Baltica palaeocontinent (Mens et al. 1990). It consists of horizontal-lying, thin-bedded and weakly-consolidated, alternating clay and siltstone layers. A combination of sedimentary structures such as ripples, desiccation crack moulds and Pascichnia-type traces indicate a shallow shelf environment (Seilacher 1967; Mens \& Pirrus 1977).

The formation is thermally and diagenetically unaltered (Mens et al. 1990; Talyzina 1998). Depositional and burial conditions rendered the preservation of microfossils exceptional, and without deformation, which allows observations of delicate wall ornamentation (processes, microsculpture on nanometre scale) and fine wall structure. The fossil record of the Lükati Formation is rich in small shelly fauna (SSF) and trace fossil diversity (Kirjanov 1987), as well as numerous palynomorph genera (Volkova et al. 1979; Talyzina \& Moczydłowska 2000; Moczydłowska 2011).

The relative age of the Lükati Formation is well constrained by index fossils and belongs to the Schmidtiellus mickwitzi faunal Zone and Skiagia ornata-Fimbriaglomerella membranacea acritarch Zone of the Cambrian biostratigraphic subdivision in Baltica (Mens et al. 1990; Moczydłowska 1991). Correlation with the global chronostratigraphic stages shows it likely lies within the time interval of 521-514 Ma (Moczydłowska 2011; Gradstein et al. 2012).

\section{Materials, methods and preservation}


This report is based mostly on scanning electron microscopy (SEM), with additional light microscopy (LM) observations on specimens obtained from the Lükati Formation.

Microfossils were originally extracted from two blue-grey claystone samples (Ko) from the Lükati Formation in Kopli Quarry via acid maceration, following standard palynological preparation methods (Vidal 1988). Rock samples were first treated with $30 \%$ hydrochloric acid $(\mathrm{HCl})$, neutralized with distilled water, left to dissolve in $40 \%$ hydrofluoric acid (HF), and filtered through the Sartorius filtering unit with $10 \mu \mathrm{m}$ mesh pore diameter. No oxidation was necessary. The acid-insoluble organic residue was stored in ethanol and mounted on SEM stubs. Stubs were then coated with $20 \mathrm{~nm}$ of Pd-Au conducting medium and scanned with a Zeiss Supra35-VP Genesis 4000 SEM.

This material was originally sampled in 1996 before the Kopli Quarry became flooded with ground water. It was reported by Talyzina \& Moczydłowska (2000) and Moczydłowska (2011), and further studied in 2013 for comparison with the Cambrian microfossils from the Kunda Quarry, Estonia (Agić et al. submitted). Only unpublished microfossils of the new species are presented here.

Organic-walled microfossils in the Lükati Formation are abundant and very well preserved, exhibiting fine details at nanometre scale, such as the exceptional porous wall structure in the new species.

All illustrated specimens are stored in the collections of the Museum of Evolution at Uppsala University, under the PMU designation. Position of the microfossils photographed via light microscope is given in England Finder coordinates.

\section{Systematic palaeontology}

Domain EUKARYA Woese et al. 1990

Group CHLOROPLASTIDA Adl et al. 2012

Division CHLOROPHYTA Pascher 1914

Class PRASINOPHYCEAE Christensen, 1980

Family TASMANACEAE Sommer 1956

Extinct Genus and Species

Genus Reticella gen. nov.

Type species. Reticella corrugata, gen. et sp. nov. 
Derivation of name. From reticello, $15^{\text {th }}$ century lace craft, in reference to the needleworklike nano-scale pores in the vesicle wall.

Diagnosis. As for type species. Monospecific genus.

Reticella corrugata sp. nov.

Plate 1, Figures 1-9; Plate 2, Figures 1-10; Plate 3, Figures 1-2

\section{Synonymy.}

1982 Micrhystridium tornatum Volkova 1968 in Downie 1982 (figure 7j)

1989 Micrhystridium tornatum Volkova 1968 in Baudet et al. 1989 (plate 2, figures 10., 11.)

1990 "unnamed coenobial cluster" in Vidal \& Nystuen 1990 (Fig. 15E)

2011 Asteridium tornatum Volkova 1968 emend. Moczydłowska 1991 in Moczydłowska 2011 (plate 21, figures 3., 6.).

2014 New species A - Agić et al. submitted (figures 4A-B.)

Holotype. Specimen PMU-Kob2-55, illustrated in Plate 2, figures 1-2.

Type locality. Kopli Quarry west of Tallinn, Estonia $\left(59.56^{\circ} \mathrm{N}, 24.67^{\circ} \mathrm{E}\right)$.

Type strata. Thin-bedded claystone of the Lükati Formation, early Cambrian undefined Series 2, the Skiagia ornata - Fimbriaglomerella membranacea acritarch Zone.

Diagnosis. LM observations. Minute spheroidal vesicle with corrugated and finely perforate wall sculpture. Wall is thin and translucent. Acetolysis-resistant. Often occurs in clusters. SEM observations. Spheroidal vesicle, with originally corrugated wall that is perforated by nano-scale pores. Wall is elastic and thin, and bears a distinct sculpture. Corrugations on the vesicle are anastomosing and convoluting, and in places intertwining. There is no intersection of the wrinkles. Pores are even in size and distribution, occurring on the corrugations as well, and are spaced ca. $30 \mathrm{~nm}$ from one another. Shape of the pores is regular and originally circular, but elongate where the wall has been stretched. Flexibility of the wall is noted in the high degree of additional deformation (wrinkling) without vesicle breakage and in stretched areas where the pores are widened.

Dimensions. Observed overall diameter of 47 measurable (not overlapping) specimens is 8.7 $\mu \mathrm{m}$, (holotype: $\mathrm{d}=8.5 \mu \mathrm{m}$ ), varying from 4.0-10.2 $\mu \mathrm{m}$. Wall thickness is measured by halving the mean wrinkle thickness, as in other corrugated acritarchs. Vesicle wall thickness of 38 specimens is: $0.1 \mu \mathrm{m}$ (holotype: $90 \mathrm{~nm}$ ). Pore diameter is 25 to $50 \mathrm{~nm}$ (mean $29 \mathrm{~nm}, \mathrm{n}=18$ ), with the distance between the pores not exceeding $40 \mathrm{~nm}$.

Material. 58 specimens, very well preserved, occurring in clusters and occasionally as free specimens. 
Stratigraphical Range. Lower Cambrian (Terreneuvian). Skiagia ornata-

Fimbriaglomerella membranacea microfossil Zone; Schmidtiellus mickwitzi trilobite Zone.

Occurrence. Kopli Quarry and Kunda Quarry, northern Estonia.

Remarks. Primary corrugation of the vesicle wall is a diagnostic morphological feature of the taxon and not a case of taphonomic wrinkling that is sometimes observed in smooth sphaeromorphic acritarchs. Taphonomic deformation was excluded as a cause of the wall sculpture pattern in another corrugated acritarch, Cerebrosphaera (Butterfield et al. 1994) as it co-occurs in the same assemblages as smooth leiosphaerids. The same is true for Reticella corrugata and other Early Paleozoic taxa with originally corrugated wall sculpture. Wall may be additionally wrinkled to its original corrugated surface (Plate 2, figures 6,10), indicating plastic deformation of the wall as the result of taphonomic compression. No vesicle fractures or excystment openings are observed. Flexibility of the wall allows for crinkling without fractures.

A porous vesicle wall is the second main feature of the new species. Pores are evenly spaced and may be deformed due to the wall stretching (Plate 2, figure 8). They strongly resemble pores that terminate in radial canals in the vesicle wall of Tasmanites. Due to their regular nature and shape consistency (Plate 2, figures 2, 4-10), they are considered as a true morphological character rather than taphonomically induced porosity. A porous vesicle is a feature observed in extant and fossil prasinophytes (Guy-Ohlson 1996; Leliaert et al. 2012). Pores in $R$. corrugata are located even on the muri-like corrugations, not just in between.

In LM observations, the corrugated sculpture may appear as "pseudo-thorns" on the vesicle outline causing misidentification as specimens pertaining to the Cambrian acanthomorph Asteridium tornatum (Moczydłowska 2011).

Specimens of $R$. corrugata tend to aggregate and form clusters (Plate 1, figures 1, 8-9). Unlike in the earlier (Proterozoic) and more common bacterial cell clusters, no evidence of a secreted sheath structure has been observed in $R$. corrugata. Clusters suggest a colonial mode of life (Batten 1996) and have been previously recorded in some Upper Cambrian galeate acritarchs (Rasul 1974), unidentified "acritarch vegetative colony growths" (Harvey et al. 2011), Asteridium tornatum (Moczydłowska 2011), Heliosphaeridium and Pterospermella (Jachowich-Zdanowska 2013). Rasul (1974) argued that acritarch clusters are formed prior to fossilization rather than during the process. However, due to the lack of a preserved sheath or extracellular polymeric substance (EPS), and considering the preparation method, there is not enough evidence to corroborate a colonial mode of life for $R$. corrugata. Instead, the clustering might be an artefact of a residue droplet drying out on the SEM stub. 
Due to their tiny size, $R$. corrugata specimens are not separated as easily as the larger forms in the same assemblage, e.g. Tasmanites or Globosphaeridium, and can even stick onto other acritarchs like a clump of kerogen (Plate 3, Figure 2).

This new species was illustrated previously in Fombella (1986), as a cluster of five vesicles from the Cambrian-Ordovician transition in the Oville Formation (Spain), but identified as a pollen tetrad (Figure 1.1. ibidem), as an "unnamed coenobial cluster" from the Brennæter shale (Vidal \& Nystuen 1990), as single cells and clusters of four vesicles identified as Micrhystridium tornatum from the Sekwi Formation (Canada) in Baudet et al. (1989) and Skiag Bridge (Scotland) in Downie (1982), and as 22 vesicles of Asteridium tornatum in Moczydłowska (2011) (also in the Lükati Formation). This indicates a widespread palaeogeographical distribution around the Avalonian Seaway (Baltica, Avalonia, Iberia, Laurentia; Figure 2).

$R$. corrugata differs from other organic-walled microfossils with a corrugated wall sculpture (Abacum, Cerebrosphaera, Dictyotidium, Palambages, Pterospermella) and pore-like perforations (Acrum, Tasmanites, Pterospermella) by having (i) considerably smaller diameter, (ii) smaller nano-scale pores, (iii) a flexible and pliable wall, and (iv) lacking an outer envelope or an equatorial flange. Notably, it shares most characters with fossils from the prasinophyte families Tasmanaceae and Pterospermellaceae, but due to the lack of aforementioned diagnostic features of those taxa, a new genus is herein erected. Derivation of name. From Latin corrugatus, $-a$, meaning wrinkled, describing the flexible and corrugated wall sculpture.

\section{Comparison with other microfossils of similar morphology}

Although Reticella corrugata from the Lükati Formation possesses unusual and unique morphology, it shares significant diagnostic characters of the vesicle wall with other palynomorphs from the Neoproterozoic Era to the Cretaceous Period (reviewed below in stratigraphic order). These similarities are discussed here for the interpretation of Reticella corrugata's biological affinities, and for a better grasp of its relationships to other microfossils, in terms of morphological and size-class groupings.

The long-ranging and extant prasinophyte Tasmanites Newton 1875 emend. Eisenack 1958, (Plate 3, figures 3-4) includes a range of morphotypes with recognizable wall perforations. It is a common and globally distributed component of palynomorph assemblages 
from the Tonian (Samuelsson et al. 1999) to Recent. Although Tasmanites is considerably larger than Reticella corrugata (comparison Plate 3, figure 1), the two fossils share remarkably similar wall structure. This porous wall was considered a diagnostic feature for its identification as a prasinophyte (Wall 1962), and homology (and eventual synonymy) with the extant alga "Pachysphaera" (Boalch \& Guy-Ohlson 1992). Tasmanites volkovae Kirjanov 1979 (Plate 3, figure 3) is very abundant in the lower Cambrian (Moczydłowska 1991; 1998), including the Lükati Formation. It is characterised by a deeply perforated phycoma wall where the pores terminate in radial canals. These are true characters and not a taphonomic feature, and they also occur in present day prasinophytes (Leliaert et al. 2012). Pores are 0.7-1 $\mu \mathrm{m}$ in diameter, evenly and densely distributed across the vesicle surface, and located in small depressions in the wall, making the vesicle outline wavy (Plate 3, figure 3). Interestingly, the ratio of pore diameter to the vesicle diameter is the same between T. volkovae and $R$. corrugata, despite the stark size differences between the two genera (Plate 3, figure 1).

The Cryogenian taxon Cerebrosphaera is among the most striking acritarchs possessing a corrugated sculpture, yet it is much larger than $R$. corrugata $(\mathrm{d}=100-900 \mu \mathrm{m})$ and possessing a thicker vesicle wall. $R$. corrugata differs from C. buickii Butterfield et al. 1994 in its smaller size, narrower corrugations, and very thin and translucent wall, where $C$. buickii appears opaque. Convolutions in R. corrugata are also sinuous and cover the entire surface of the vesicle. They are not, however, as tight and regularly distributed as in Cerebrosphaera, probably due to plasticity of the wall. Perforations in the wall present in some specimens of $C$. buickii are wider $(2 \mu \mathrm{m})$ and more randomly distributed than the nanopores of $R$. corrugata, and are thought to be the result of protistan predation (Porter 2011) rather than a true biological character.

The genus Pterospermella Eisenack 1972 (Prasinophyta) occurs in the fossil record from Proterozoic to Holocene (Guy-Ohlson 1996; Samuelsson et al. 1999) and is characterised by a phycoma-like morphology of an inner body surrounded by an outer envelope. Some of its species share strong similarities between their phycoma central bodies and the morphology of $R$. corrugata wall (e.g. Colbath 1983, figure 44). P. circumstriata Wicander 1986 from the Lower Devonian Haragan Formation, Oklahoma bears concentric ridges on the surface which crinkle towards the centre of the vesicle and also stretch into uneven flanges (Tappan 1980, figure 10.17.3) showing the same flexibility of the wall as in $R$. corrugata. The diameter of $P$. circumstriata is larger, 20-35 $\mu$ m including the outer phycoma-like envelope; and 10-15 $\mu \mathrm{m}$ just for the central body. Thin corrugations and unevenly distributed "wrinkling" pattern are present in both species. $R$. corrugata resembles 
only one element of $P$. circumstriata, and otherwise differs from it in lacking the broad equatorial flange and the outer envelope that are the main feature of the genus. However, differing sculptural pattern between elements of the same species occur in other organicwalled microfossils (Moczydłowska 2015). This similarity is worth noting with respect to the formation mechanism of the conspicuous corrugated sculpture. Distinct wall sculpture is a common morphological feature of central structures in prasinophyte phycomas, especially in the family Pterospermallaceae (Guy-Ohlson 1996).

In LM imagery, $R$. corrugata also resembles the minute (ca. $15 \mu \mathrm{m})$ lower to Middle Cambrian acritarch Acrum novum Fombella 1978, the only species of Acrum without processes, but having a faint surface sculpture. However, surface reticulation in A. novum is of a larger scale than the pores of $R$. corrugata, and individual fields are ca. $1 \mu \mathrm{m}$ in diameter.

Clustered specimens of Reticella corrugata have been illustrated previously with light microscope, but identified as Asteridium tornatum Volkova 1968 emend.

Moczydłowska 1991 from the early Cambrian of Estonia (Moczydłowska 2011, Figures 21.3., 21.6.), and are synonymized herein. Minute and often clustering vesicles of A. tornatum fall into the same size and age range as $R$. corrugata. Whereas some Asteridium species possess more conspicuous processes, those of A. tornatum are very short and thorn-like, which makes them difficult to observe in LM. These tiny processes superficially resemble the dotted pattern of pores and wrinkles in R. corrugata (Plate 1, figure 8). In poorly preserved specimens, SEM studies are needed to identify the presence of nano-pores and distinguish between the two taxa. Moczydłowska (1991) noted compaction folds on the A.tornatum wall, which are also similar to the sculpture of $R$. corrugata.

Abacum normale Fombella 1978 is a corrugated sphaeromorphic acritarch occurring in the Middle-Upper Cambrian (Palacios et al. 2011). Its size range is larger than $R$. corrugata $(\mathrm{d}=20-30 \mu \mathrm{m})$. Corrugations are thicker and there are no pores in the wall. $R$. corrugata does not possess a smooth equatorial band that is sometimes present in A. normale, but it is unclear whether the band is a taphonomic feature or diagnostic morphology. Abacum sculpture was described as "groves and muri of equal width" (Fombella 1978; Vanguestaine \& Brück 2008). Muri (or valla) is a term more commonly used in pollen studies, referring to the raised, flap-like elements on the wall separated by groves but may also be used when alluding to prasinophytes (Traverse 2007). However, the sculptural elements of Abacum vary in thickness and density which makes them less regular than typical muri or folding patterns of other corrugated microfossils (Fombella 1979, Figures 8, 53 ibidem). 
One developmental stage of the Cambrian chlorophyte Polygonium varium also exhibits a corrugated wall sculpture (Moczydłowska 2015), but lacks any perforations and it is generally larger than the Lükati small acritarchs (ca. $25 \mu \mathrm{m}$ ). Corrugations are only observed on its internal body which is inferred to represent an endocyst.

Some of the specimens attributed to Micrhystridium may be recognised as Reticella corrugata (e.g. Downie 1982; Baudet et al. 1989). Micrhystridium is a long-ranging taxon recorded throughout the Phanerozoic counting numerous form-species with or without ornamentation or sculpture, and of a wide range of morphologies. Unsurprisingly, Micrhystridium was dubbed a "waste-basket genus" (Sarjeant \& Stancliffe 1994) which led to revisions of the plexus (Lei et al. 2013). Many subsequent studies relied on SEM observations to put more reliable taxonomic constraints on the small acritarchs (Schrank 2003). Moczydłowska (1991) erected a new acanthomorph genus Asteridium, also including some Cambrian morphotypes of Micrhystridium to differentiate between the double wall of the Mesozoic Micrhystridium morphotypes and the Cambrian taxa with a single wall and solid or open processes (Asteridium and Heliosphaeridium respectively).

Chlorococcacean fossil Palambages morulosa Wetzel 1961 from the Upper Cretaceous of Germany (Tappan 1980) likewise occurs in clusters and possesses a translucent and lightly corrugated wall, making it highly similar to $R$. corrugata in LM. Both microfossils are in the same size range, ca. 4-10 $\mu \mathrm{m}$ in diameter, but unlike the porous wall of $R$. corrugata, $P$. morulosa has a homogenous wall with a single round excystment opening (2-3 $\mu \mathrm{m}$ in diameter).

The Mesozoic prasinophyte Schizophacus rugulatus Cookson \& Dettman 1959 also shows corrugated wall morphology and similar size range as $R$. corrugata. However, individual sculpture elements are thicker, tightly arranged and more evenly spaced on the vesicle surface. Folds are also smaller in relation to vesicle diameter than in $R$. corrugata.

\subsection{Biological affinity}

Microfossils that share most phenotypical similarities with Reticella corrugata gen. et sp. nov. are the long-ranging taxa Tasmanites and certain Pterospermella morphotypes, both considered to be "undisputedly prasinophytes" (Fensome et al. 1990; Playford 2003; Dutta et al. 2006). Following these comparisons, $R$. corrugata may be confidently placed within the class Prasinophyceae (Chlorophyta), on the basis of unique and 
well preserved characters of the wall sculpture (corrugated vesicle and porous wall) that are common among both recent prasinophytes and fossil taxa ranging from Neoproterozoic to Neogene. Furthermore, tiny pores are especially common in the family Tasmanaceae (Sommer 1956; Wall 1962; Muir \& Sarjeant 1971; Guy-Ohlson 1996), and rare outside of the genera Tasmanites and Maculatisporites. Minute fossils from the Lükati Formation differ from the aforementioned two taxa in their particularly small size and corrugated vesicle, so they likely belong to a separate genus, but within the same prasinophyte family.

Even though the prasinophyte algae are paraphyletic (Leliaert et al. 2012), the ancient fossil forms (Tasmanites/Pachysphaera and Pterosperma-like taxa) cluster within the same prasinophyte division Pyramimonadales (Turmel et al. 2009). Recent species within this group also possess a porate vesicle, so it is likely that this character is a synapomorphy between the larger Tasmanites and smaller Reticella, rather than a result of convergent evolution.

\section{The early Cambrian radiation and appearance of small acritarchs}

The Cambrian explosion (starting at $555 \mathrm{Ma}$, Martin et al. 2000) is a major milestone in the history of life. Apart from the rapid, stepwise animal evolution at this time (e.g. Maloof et al. 2010; Budd 2013), this event was also marked, and to an extent, fuelled by a major radiation of eukaryotic primary producers (Vidal \& Moczydłowska-Vidal 1997; Moczydłowska 2002; Grey 2007), that continued to diversify into the Great Ordovician Biodiversification Event (Servais et al. 2008). Phytoplankton evolution at the ProterozoicPhanerozoic transition shows a trend for the reduction in cell size, observed in the rapid diversification of small sphaeromorphic and acanthomorphic acritarchs at the beginning of the Cambrian (Moczydłowska 1991; Vidal \& Moczydłowska 1992; Knoll 1994; Butterfield 1997), in contrast to the older ECAP community (Ediacaran Complex Acanthomorph Palynoflora, Grey 2005). This could have been the effect of exploiting the picoplankton niche that had opened up as a result of potential rapid removal of small sized phytoplankton by the newly evolved sponges (Lenton et al. 2014), which appeared by at least $600 \mathrm{Ma}$ (Yin et al. 2015).

The oldest record of tiny eukaryotes is, however, the Ediacaran occurrence of nanoscale spheroidal microfossils (3-5 $\mu \mathrm{m}$ in diameter) of unknown affinities from the Doushantuo Formation, China (Borjigin et al. 2014). Nano-spheroids were compared to chroococcacean 
cyanobacteria and fungal spores, but the assemblage also includes a specimen with rows of minute pores "akin to unicellular algae." The authors have stated that the character of minute holes along the margin is unknown in other extant or fossil taxa. Nonetheless, equally distributed or localised tiny perforations in the wall are a common feature among prasinophytes (Guy-Ohlson 1996; Leliaert et al. 2012) recorded in the Mesozoic and Cambrian (herein), and could point to a more specific biological affinity of the Ediacaran nano-sphaeroids.

More diverse small acritarchs i.e. prokaryote-size organic-wall microfossils with distinct eukaryotic affinity (wall sculpture), appeared at the base of the Cambrian, within the assemblages documenting the radiation of numerous new palynomorph genera and species, which have been interpreted as phytoplankton (Volkova 1968; Jankauskas 1975; Downie 1982; Moczydłowska 1991; 2011; Fuxing \& Qiao 1987; Baudet et al. 1989). Morphologically diverse, ornamented or sculptured, and of consistently small dimensions, these taxa have been mostly overlooked due to their size, not recorded, or lost in sample processing. They are persistent components of the Cambrian microfossil associations and have well recognized stratigraphic ranges in relation to faunal zones. Ranges of certain form-genera are substantial in geologic time intervals and may span almost the entire Cambrian Period, but form-species tend to be short ranging and show a fast turnover (Vidal \& Moczydłowska-Vidal 1997). Limited in taxonomic diversity in comparison to other palynomorph taxa, and infrequently recorded because of the preservation and methodological recovery bias, the so-called small acritarchs are still recorded throughout the Phanerozoic.

The name "small acritarchs" for organic-walled fossils ca. 5-10 $\mu \mathrm{m}$ in diameter, was first used by Habib \& Knapp (1982) in the detailed SEM study of the Cretaceous assemblage from the Deep Sea Drilling Project in the western North Atlantic. However, such minute taxa have been known from the Cambrian (Volkova 1968; Vanguestaine 1974; Fombella 1979, 1986; Vavrdová 1982; Moczydłowska 1991; 2011), Palaeozoic (Tappan \& Loeblich 1973; Loeblich \& Wicander 1976; Playford 1981; Colbath 1983; Parsons et al. 2000; Le Hérissé 2002), and Mesozoic-Cenozoic (Habib \& Knapp 1982; Shrank 2003; Lei et al. 2013; Amenábar et al. 2014). Presence of the poorly-resolved small acritarch Micrhystridium throughout Phanerozoic strata is also interesting. Even if Micrhystridium includes many different taxa (Lei et al. 2013), the longevity of this size-morphotype in the rock record may be of significance for appreciating the abundance of small acritarchs or picoplankton through the geological history. 
Diversity of these minute microfossils is likely even higher considering the amount overlooked in the studies based solely on light microscopy, and there is already a size bias in the fossil record against the biodiversity of smaller organisms (Cooper et al. 2006). For example, it is difficult to distinguish between Reticella corrugata and Asteridium tornatum without the use of SEM - quite an important tool in acritarch research, especially when considering taxonomy (Servais 1996). Recent work on small acritrachs led to an increased number of SEM-based taxa (Schrank 2003). This ample record of small acritrachs throughout the Phanerozoic suggests they were an integral part of the past marine phytoplankton communities, parallel to the present day picoplankton.

Eukaryotic picoplankton or picoeukaryotic algae (Foulon et al. 2008) are only recently acknowledged as a major portion of the biomass in modern marine ecosystems (Lewin et al. 2000) and may have occupied similar environments and played an adequate role as photosynthesizers beside bacteria throughout the geological history. Even through occasional insights by their fossils, they provide important evidence of the ecological complexity among primary producers. The size-group of "small acritarchs" represents the fossil record of eukaryotic picoplankton and its record is extended back from the Cretaceous to the Cambrian. The body size of this ecological grouping is not fully constrained. Eukaryotic components of the picoplankton are larger than cyanobacteria and some picoprasinophytes may grow up to $6.5 \mu \mathrm{m}$ in culture (Lewin et al. 2000). There is also an overlap of sizes between the eukaryotic picoplankton and the nanoplankton $(2-20 \mu \mathrm{m})$. Therefore, in addition to size, biological affinity should also be relevant when assigning fossils to this group.

Most of the mentions of picoplankton with respect to the fossil record assume cyanobacterial affinity for this size-class (Golubic \& Seong-Joo 1999). In their discussion on the primary producers in ancient oceans, Knoll et al. (2007) consider picoplankton unlikely to become preserved, yet recognize the preservation potential of other microalgae, such as prasinophytes. Seeing the abundance of prasinophyte taxa constituting the modern eukaryotic picoplankton, it is not unexpected to find some of them fossilized.

Prasinophyte components of small acritarchs such as Reticella corrugata gen. et sp. nov., could have filled the niche of the eukaryotic picoplankton since their lowest occurrence at the beginning of the Phanerozoic.

\section{Summary}


New fossil material was recovered and studied from the lower Cambrian Lükati Formation exposed in the Kopli Quarry, Estonia. Lükati Formation did not undergo diagenetic alteration, which resulted in exceptional preservation of organic-walled microfossils of conspicuously small size $(4-10.2 \mu \mathrm{m})$. The new genus and species have been erected for these tiny fossils: Reticella corrugata (Plate 1-2). This new taxon is characterized by a porate vesicle with corrugated wall sculpture, and minute dimensions. Counting the synonymized taxa from the Brennæter shale (Norway), Sekwi Formation (Canada), Oville Formation (Spain), and Skiag Bridge (Scotland), Reticella had a widespread palaeogeographical distribution around the Avalonian Seaway (Baltica, Laurentia, Iberia and Avalonia; Figure 2).

$R$. corrugata was compared to morphologically similar microfossils from different time periods to ascertain its biological affinities. It shares most characteristics with the prasinophyte Tasmanites, as well as some elements with Pterospermella. Both of these taxa have a long ranging fossil record dating back to the Neoproterozoic, and recognized affinity to the prasinophyte algae.

$R$. corrugata reflects the evolutionary trend of size reduction in phytoplankton at the beginning of Paleozoic. However, while most of the Cambrian smallsized phytoplankton is composed of acanthomorphic acritarchs such as Asteridium and Heliosphaeridium, R. corrugata lacks processes and exhibits unique morphology. Particularly minute organic-walled microfossils in the Mesozoic were grouped into the size-class "small acritarchs", and these forms occur throughout the Phanerozoic. Small acritarchs represent a parallel to the modern eukaryotic picoplankton. The later was only recently identified and the fossil record of the group was not examined in great detail. As a prasinophyte component of small acritarchs, Reticella could imply the presence of eukaryotic picoplankton or picoprasinophytes as early as the Lower Palaeozoic.

The newly recovered minute microfossils, in addition to those previously known in contemporaneous strata and comprising different classes of green algae and some taxa of unknown affinities, enrich the biodiversity and ecosystem tiering in the Cambrian.

\section{Acknowledgements}

This paper benefitted greatly from constructive comments by M. Moczydłowska (Uppsala University). S. Willman (UU) provided valuable feedback. Presented work is a part of the 
author's PhD project and was funded by the Swedish Research Council (VR) grant no. 6212012-1669.

\section{References}

Adl, SM, Simpson, AG, Lane, CE, Lukeš, J, Bass, D, Bowser, SS, Brown, M, Burki, F, Dunthorn, M, Hampl, V, Heiss, A, Hoppenrath, M, Lara, E, leGall, L, Lynn, DH, McManus, H, Mitchell, EAD, Mozley-Stanridge, SE, Wegener Parfrey, L, Pawlowski, J, Rueckert, S, Shadwick, L, Schoch, C, Smirnov, A, Spiegel, FW. 2012. The revised classification of eukaryotes. J. Eukar. Microbiol. 59:429-514.

Agić, H, Moczydłowska, M, Canfield, DE. Reproductive cyst and operculum formation in the Cambrian-Ordovician galeate-plexus algal microfossils. Submitted to Acta Pal. Pol.

Amenábar, C, Candel, MS, Guerstein, R. 2014. Small Antarctic late Cretaceous chorate dinoflagellate cysts: biological and palaeoenvironmental affinities. Palynology 38:303-323.

Batten, DJ. 1996. Colonial Chlorococcales. In: Jansonius, J, McGregor, DC (eds). Palynology: Principles and Applications. American Association of Stratigraphic Palynologists Fundation 1, 205-214.

Baudet, D, Aitken, JD, Vanguestaine, M. 1989. Palynology of uppermost Proterozoic and lowermost Cambrian formations, central Mackenzie Mountains, northwestern Canada. Can. J. Earth Sci. 26:129-148.

Boalch, GT, Guy-Ohlson, D. 1992. Tasmanites, the correct name for Pachysphaera (Prasinophyceae, Pterospermataceae). Taxon 41:529-531.

Boalch, GT, Parke, M. 1971. The Prasinophycean genera (Chlorophyta) possibly related to fossil genera, in particular the genus Tasmanites. In: Proceedings of the II Planktonic Conference p.99-105. 
Borjigin, T, Yin, L, Bian, L, Yuan, X, Zhou, C, Meng, F, Xie, X, Bao, F. 2014. Nanoscale spheroids and fossils from the Ediacaran Doushantuo Formation in China. The Open Paleo. J. $5: 1-9$.

Budd, GE. 2013. At the origin of animals: the revolutionary Cambrian fossil record. Curr. Genomics 14:344-354.

Butterfield, NJ, Knoll, AH, Swett, K. 1994. Paleobiology of the Neoproterozoic Svanbergfjellet Formation, Spitsbergen. Fossils \& Strata 34:1-84.

Butterfield, NJ. 1997. Plankton ecology and the Proterozoic-Phanerozoic transition. Paleobiology 23:247-262.

Colbath, GK. 1983. Fossil prasinophycean phycomata (Chlorophyta) from the Silurian Bainbridge Formation, Missouri, USA. Phycologia 22:249-265.

Cookson, IC, Dettmann, ME. 1959. On Schizosporis, a new genus from the Australian Cretaceous deposits. Micropaleontology 5:213-216.

Cooper, RA, Maxwell, PA, Crampton, JS, Beu, AG, Jones, CM, Marshall, BA. 2006. Completeness of the fossil record: estimating losses due to small body size. Geology 34:241244.

Courties, C, Vaquer, A, Troussellier, M, Lautier, J. 1994. Smallest eukaryotic organism. Nature 370:255.

Downie, C. 1973. Observations on the nature of the acritarchs. Palaeontology 16:239-259.

Downie, C. 1982. Lower Cambrian acritarchs from Scotland, Norway, Greenland and Canada. Trans. Royal Soc. Edinburgh 72:257-285.

Dutta, S., Greenwood, PF, Brocke, R, Schaefer RG, Mann, U. 2006. New insights into the relationship between Tasmanites and tricyclic terpenoids. Org. Geochem. 37:117-127. 
Eisenack, A. 1985. Tasmanites Newton und Leiosphaeridia n.g. als Gattungen der Hystrichosphaeridea. Palaeontographica 110:1-19.

Fensome, RA, Williams, GL, Barrs, MS, Freeman, JM, Hill, JM. 1990. Acritarchs and fossil prasinophytes: an index to genera, species and infraspecific taxa. AASP Contributions Series 25:1-771.

Fombella, MA. 1978. Acritarchos de la Formación Oville, edad Cámbrico Medio - Tremadoc, provincia de León, España. Palinologia, num. extraord. 1:245-621.

Fombella, MA. 1979. Palinología de la Formación Oville al Norte y Sur de la Cordilliera Cantábrica, España. Palinologia 1:1-13.

Fombella, MA. 1986. El transito Cambrico-Ordovicico, palinologia y diacronismo, provincial de Leon, no de España. Rev. Esp. de Micropal. 2:165-179.

Foulon, E, Not, F, Jalabert, F, Cariou, T, Massana, R, Simon, N. 2008. Ecological niche partitioning in the picoplanktonic green alga Micromonas pussila: evidence from environmental surveys using phylogenetic probes. Environ. Microbio. 10:2433-2443.

Fuxing, W, Qiao, C. 1987. Spiniferous acritarchs from the lowest Cambrian, Emei, Sichuan, southwestern China. Rev. Palaeobot. Palynol. 52:161-177.

Golubic, S, Seong-Joo, L. 1999. Early cyanobacterial fossil record: preservation, palaeoenvironments and identification. Eur. J. Phycol 34:339-348.

Gradstein, F, Ogg, J, Schmitz, M, Ogg, G. 2012. The Geologic Time Scale 2012. Elsevier p.1144.

Grey, K. 2005. Ediacaran palynology of Australia. Memoir 31 of the Association of Australasian Palaeontologists, p.439. 
Grey, K. 2007. The world of the very small: fuelling the Animalia. In: Fedonkin, MA, Gehling, JG, Grey, K, Narbonne, GM, Vickers-Rich, P. The rise of Animals: evolution and diversification of the kingdom Animalia. John Hopkins University Press, p.219-231.

Guy-Ohlson, D. 1996. Prasinophycean algae. In: Jansonius, J., McGregor, DC, editors. Palynology: Principles and applications. AASP Foundation, p.181-189.

Habib, D, Knapp, SD. 1982. Stratigraphic utility of Cretaceous small acritarchs. Micropaleontology 28:335-371.

Harvey, THP, Ortega-Hernández, J, Lin, J., Yuanlong, Z, Butterfield, NJ 2011. Burgess Shale-type microfossils from the middle Cambrian Kaili Formation, Guizhou Province, China. Acta Pal. Pol. 57:423-436.

Jachowicz-Zdanowska, M. 2013 Cambrian phytoplankton of the Brunovistulicum - taxonomy and biostratigraphy. Polish Geological Institute Special Papers 28:1-149.

Jankauskas, TV. 1975. New Lower Cambrian acritarchs of the Baltic region. Paleontol. Zh. Akad. Nauka SSSR 1:94-104.

Joint, IR. 1987. Physiological ecology of picoplankton in various oceanographic provinces. In: Platt, T, Li, KW. Photosynthetic picoplankton. Can. Bull. Fish. Aquat. Sci. 214:287-309.

Kirjanov, VV. 1978. Akritarchi Silura Volyno-Podoli. Nauka Dumka, Kiew, p.114. (in Russian)

Kirjanov, VV. 1979. The Cambrian. In: Keller, BM, Rozanov, AY. Upper Precambrian and Cambrian stratigraphy of the western part of the East European Platform. Nauka, Moscow p.151-177. (in Russian)

Kirjanov, VV. 1987. Talsy stage. In: Rozanov, AY, Lydka, K, editors. Palaeogeography and lithology of the Vendian and Cambrian of the western East European Platform. Wydawnictwa Geologiczne, Warsaw, p.37-44. 
Knoll, AH. 1994. Proterozoic and Early Cambrian protists: evidence for accelerating evolutionary tempo. PNAS 91:6743-6750.

Knoll, AH, Summons, RE, Waldbauer, JR, Zumberge, JE. 2007. The geological succession of primary producers in the oceans. In: Falkowski, PG, Knoll, AH. (eds.) Evolution of primary producers in the sea. Elsevier, p.133-163.

Knoll, AH. 2014. Paleobiological perspectives on early eukaryotic evolution. Cold Spring Harbor perspectives in biology 6: a016121.

Le Hérissé, A. 2002. Paleoecology, biostratigraphy and biogeography of late Silurian to early Devonian acritarchs and prasinophycean phycomata in well A161, Western Libya, North Africa. Rev. Palaeobot. Palynol. 118:359-395.

Lei, Y, Servais, T, Feng, Q, He, W. 2013. Latest Permian acritarchs from South China and the Micrhystridium/Veryachium complex revisited. Palynology 37:325-344.

Leliaert, F, Smith, DR, Moreau, H, Herron, MD, Verbruggen, H, Delwiche, CF, De Clerck, O. 2012. Phylogeny and molecular evolution of the Green Algae. Crit. Rev. Plant Sci. 31:146.

Lenton, TM, Boyle, RA, Poulton, SW, Shields-Zhou, GA, Butterfield, NJ. 2014. Co-evolution of eukaryotes and ocean oxygenation in the Neoproterozoic era. Nature Geoscience 7:257265.

Lewin, RA, Krienitz, L, Goericke, R, Takeda, H, Hepperle, D. 2000. Picocystis salinarum gen. et sp. nov. (Chlorophyta) - a new picoplanktonic green alga. Phycologia 39:560-565.

Loeblich, AR, Wicander, RE. 1976. Organic-walled microplankton from the Lower Devonian Late Gedinnian Haragan and Boid d'Arc formations of Oklahoma, USA. Palaeontographica Abteilung B 1-39. 
Maloof, AC, Porter, SM, Moore, JL, Dudás, FÖ, Bowring, SA, Higgins, JA, Fike, DA, Eddy, MP. 2010. The earliest Cambrian record of animals and ocean geochemical change. GSA Bulletin 122:1731-1774.

Martin, MW, Grazhdankin, DV, Bowring, SA, Evans, DAD, Fedonkin, MA, Kirschvink, JL. 2000. Age of Neoproterozoic bilaterian body and trace fossils, White Sea, Russia: implications for metazoan evolution. Science 288:841-845.

McKerrow, WS, Cocks, LRM. 1995. The use of biogeography in the terrane assembly of the Variscan belt of Europe. Studia Geophys. Geodet. 39:269-275.

Meakin, NG, Wuman, M. 2011. Rapid shifts in picoeukaryote community structure in response to ocean acidification. The ISME Journal 5:1397-1405.

Mens, K, Pirrus, EA. 1977. Stratotypes of the Cambrian Formations of Estonia. Valgus, Tallinn.

Mens, K, Bergström, J, Lendzion, K. 1990. The Cambrian System on the East European Platform, Publication No.25 International Union of Geological Sciences, Trondheim.

Moczydłowska, M. 1991. Acritarch biostratigraphy of the Lower Cambrian and the Precambrian-Cambrian boundary in southeastern Poland. Fossils \& Strata 29:1-127.

Moczydłowska, M. 1998. Cambrian acritarchs from Upper Silesia, Poland - biochronology and tectonic implications. Fossils \& Strata, 46:1-124.

Moczydłowska, M. 2002. Early Cambrian phytoplankton diversification and appearance of trilobites in the Swedish Caledonides with implications for coupled evolutionary events between primary producers and consumers. Lethaia 35:191-214.

Moczydłowska, M. 2011. The early Cambrian phytoplankton radiation: acritarch evidence from the Lükati Formation, Estonia. Palynology 35:103-145. 
Moczydłowska, M, Landing, E, Zang, W, Palacios, T. 2011. Proterozoic phytoplankton and timing of chlorophyte algae origins. Palaeontology 54:721-733.

Moczydłowska, M. 2015. Algal affinities of the Ediacaran and Cambrian organic-walled microfossils with internal reproductive bodies: Tanarium and other morphotypes. Palynology, in press.

Muir, MD, Sarjeant, WAS. 1971. An annotated bibliography of the Tasmanaceae and related living forms (Algae: Prasinophyceae). Microfos. Org. du Paleoz. 3:51-117.

Newton, ET. 1875. On “Tasmanite” and Australian "white coal”. Geol. Mag. 2:337-343.

Palacios, T, Jensen, S, White, CE, Barr, SM. 2011. Cambrian acritrachs from the Bourinot belt, Cape Breton Island, Nova Scotia: age and stratigraphic implications. Can. J. Earth Sci. 49:289-307.

Parsons, MG, Anderson, MM, Molyneux, SG, Dorning, KJ. 2000. Acritarch microfloral succession form the Late Cambrian and Ordovician (early Tremadoc) of Random island, eastern Newfoundland, and its comparison to coeval microfloras, particularly to those of the East European Platform. AASP Foundation, No.38.

Playford, G. 1981. Late Devonian acritrachs from the Gneudna Formation in the western Carnarvon Basin, Western Australia. Geobios 14:145-171.

Playford, G. 2003. Acritarch and prasinophyte phycomata: a short course. AASP Contributions Series 41:1-46.

Porter, SM. 2011. The rise of predators. Geology 39:607-608.

Samuelsson, J, Dawes, PR, Vidal, G. 1999. Organic-walled microfossils from the Proterozoic Thule Supergroup, Northwest Greenland. Precambrian Res. 96:1-23. 
Sarjeant, WAS, Stancliffe, RPW. 1994. The Micrhystridium and Veryhachium complexes (Acritarcha: Acanthomorphitae and Polygonomorphitae): a taxonomic reconsideration. Micropaleontology 40:1-77.

Schrank, E. 2003. Small acritrachs from the Upper Cretaceous: taxonomy, biological affinities and paleoecology. Rev. Palaeobot. Palynol. 123:199-235.

Seilacher, A. 1967. Bathymetry of trace fossils. Mar. Geol. 5:413-428.

Servais, T. 1996. Some considerations on acritarch classification. Rev. Palaeobot. Palynol. 93:9-22.

Servais, T, Lehnert, O, Li, J, Mullins, GL, Munnecke, A, Nützel, A, Vecoli, M. 2008. The Ordovician Biodiversification: revolution in the oceanic trophic chain. Lethaia 41:99-109.

Sommer, FW. 1956. South American Paleozoic sporomorphae without haptotypic structures. Micropaleontology 2:175-181.

Stockner, JG. 1988. Phototrophic picoplankton: an overview from marine and freshwater ecosystems. Limnology and Oceanography 33:765-775.

Talyzina, NM 1998. Fluorescence intensity in Early Cambrian acritarchs from Estonia. Rev. Palaeobot. Palyn. 100:99-108.

Talyzina, NM, Moczydłowska, M. 2000. Morphological and ultrastructural studies of some acritarchs from the Lower Cambrian Lükati Formation, Estonia. Rev. Palaeobot. Palyn. $112: 1-21$.

Tappan, HN, Loeblich, AR. 1973. Evolution of oceanic plankton. Earth Sci. Rev. 9:207-240.

Tappan, HN. 1980. The paleobiology of plant protists. WH Freeman p.1028.

Traverse, A. 2007. Paleopalynology, $2^{\text {nd }}$ edition. Springer p.813. 
Turmel, M, Gagnon, MC, O’Kelly, CJ, Otis, C, Lemieux, C. 2009. The chloroplast genomes of the Green Algae Pyramimonas, Monomastix, and Pycnococcus shed new light on the evolutionary history of prasinophytes and the origin of the secondary chloroplasts in euglenids. Mol. Biol. Evol. 26:631-648.

Vanguestaine, M. 1974. Especès zonales d'acritarches du Cambro-Trémadocien de Belgique et de l'Ardenne française. Rev. Palaeobot. Palynol. 18:63-82. (in French with English abstract)

Vanguestaine, M, Brück, PM. 2008. A Middle and Late Cambrian age for the Booley Bay Formation, County Wexford, Ireland: new acritarch data and implications. Rev. micropal. 51:67-95.

Vavrdová, M. 1982. Phytoplankton communities of Cambrian and Ordovician age of central Bohemia. Věst. Ústř. Úst. Geol. 57:145-155.

Vidal, G. 1988. A palynological preparation method. Palynology 12:215-220.

Vidal, G, Nystuen, JP. 1990. Lower Cambrian acritrachs and the Proterozoic-Cambrian boundary in southern Norway. Norsk Geologisk Tidsskrift 70:191-222.

Vidal, G, Moczydłowska, M. 1992. Patterns of phytoplankton radiation across the Precambrian-Cambrian boundary. Journal of the Geological Society 149:647-564.

Vidal, G, Moczydłowska-Vidal, M. 1997. Biodiversity, speciation, and extinction trends of Proterozoic and Cambrian phytoplankton. Paleobiology 23:230-246.

Volkova, NA. 1968. Acritarchs from the Precambrian and lower Cambrian deposits in Estonia. In: Volkova, NA, Zabrodin, VE, Klinger, B. Russian problematics pf Riphean and Cambrian layers of the Russian Platform Urals and Kazakhstan. Nauka, Moscow p.8-36. (in Russian)

Volkova, NA, Kirjanov, VV, Piskun, LV, Paškevičiené, LT, Jankauskas, TV. 1979.

Rastitelnye mikrofossilii. In: Keller, BM, Rozanov, AY. Paleontologiya 
verkhnedokembrijskikh i kembrijskikh otlozhenij Vostocno-Evropejskoj platformy, Moskva p. 4-38.

Wall, D. 1962. Evidence from recent plankton regarding the biological affinities of Tasmanites Newton 1875 and Leiosphaeridia Eisenack 1958. Geol. Mag. 99:353-363.

Wetzel, O. 1961. New microfossils from Baltic Cretaceous flintstones. Micropaleontology 7:337-350.

Wicander, R. 1986. Lower Devonian (Gedinnian) acritarchs from the Haragan Formation, Oklahoma, USA. Rev. Palaeobot. Palynol. 47:327-365.

Yin, Z, Zhu, M, Davidson, EH, Bottjer, DJ, Zhao, F, Tafforeau, P. 2015. Sponge grade body fossil with cellular resolution dating $60 \mathrm{Myr}$ before the Cambrian. PNAS doi/10.1073/pnas.1414577112.

\section{Figure captions:}

Plate 1. Organic-walled microfossil Reticella corrugata gen. et sp. nov. from the Lükati Formation preserved as unicells and in clusters. Figures 1-7. Scanning electron micrographs (SEM). Figures 8-9. Transmitted light microscopy photomicrographs. 1-8. Specimens derive from the Lükati Formation exposed in the Kopli Quarry. 9. Specimens derive from the lower Cambrian (Cm2) of Kunda Quarry. 1. Cluster of 12 specimens, partially overlapping and still adherent after maceration and mounting. PMU-Ko5-06. 2. PMU-Ko5-02. 3. PMU-Ko5-03. 4. PMU-Ko4-13. 5. PMU-Ko5-06. 6. PMU-Ko5-07. 7. PMU-Kob2-10. 8. Cluster of corrugated sphaeromorphs from the Lükati Formation, originally identified and illustrated as Asteridium tornatum Volkova 1968 in Moczydłowska 2011 (plate 21. figure 6. ibidem), reprinted with permission. PMU-ES-Ko-96-5 (C30/4). 9. Cluster of R.corrugata from the Cambrian strata in Kunda Quarry. PMU-L988 (G40/4). Scale bars 1,7= 5 $\mu \mathrm{m} ; 2-6=2 \mu \mathrm{m} ; 8-9=10 \mu \mathrm{m}$.

Plate 2. SEM vesicle wall details and nano pores of Reticella corrugata . Figures 1-2 Holotype in full view and under higher magnification, with flexible corrugated wall perforated by dense pores. PMU-Kob2-55. Figure 3. Specimen with highly convoluted folds, 
indicating a significant degree of vesicle wall flexibility. PMU-Kob2-28c. Figure 4. PMUKo5-03. Figure 5. PMU-Ko4-13a. Figure 6. PMU-Ko5-08. Figure 7. Higher magnification of the specimen PMU-Ko4-13 (Plate 1.4.). Thickness of the wall can be observed on the edge of the folds, between individual pores. Figure 8. Specimen with stretched wall. Pores may stretch to $5 \mathrm{~nm}$ in diameter. PMU-Ko5-06h. Figure 9. PMU-Ko5-06i. Figure 10. Higher magnification of the specimen PMU-Ko5-02 (Plate 1.2.). Scale bars $1,3=2 \mu \mathrm{m} ; 2,4-6,9-10$ $=500 \mathrm{~nm} ; 7-8=300 \mathrm{~nm}$.

Plate 3. Size and wall structure comparison between Reticella corrugata and other early Cambrian sphaeromorph and prasinophyte microfossils in the Lükati Formation. Figure 1. Prasinophyte Tasmanites bobrowskae Wazynska 1967, overlain by a single specimen of $R$. corrugata on the left (arrow). PMU-Kob2-08. Figure 2. Leiosphaeridia sp. Eisenack 1958. overlain by two $R$. corrugata specimens in the middle. PMU-Kob2-11. Figure 3. Dense pores creating indentations in the wall (radial canals) in Tasmanites volkovae Kirjanov 1979. PMUKo5-34. Figure 4. Widely spread pores in the wall sculpture of Tasmanites tenellus Volkova 1968. PMU-Ko5-13. Scale bars 1-2 $=20 \mu \mathrm{m} ; 3-4=5 \mu \mathrm{m}$.

Figure 1. Geological map of Estonia and the position of Estonia in relation to the Baltic Sea. The Cambrian Lükati Formation is exposed in the Kopli Quarry (marked by a star), located on the northern shore of Estonia near Tallinn, facing the Gulf of Finland. Modified from the Geological Map of Estonia, Geological Survey of Estonia (EGK).

Figure 2. Distribution of Reticella corrugata occurrences in the Cambrian. Comparable acritarch assemblages from the early Cambrian are marked with shaded fields on the palaeogeographical reconstruction of the continents at the early Cambrian. Records of $R$. corrugata from the Lükati Formation, Estonia, as well as synonymized records from the Brennæter shale, Norway; Skiag Bridge, Scotland; Oville Formation, Spain and Sekwi Formation, Canada, are marked with black dots. Modified from McKerrow \& Cocks 1995 and Moczydłowska 1998. 


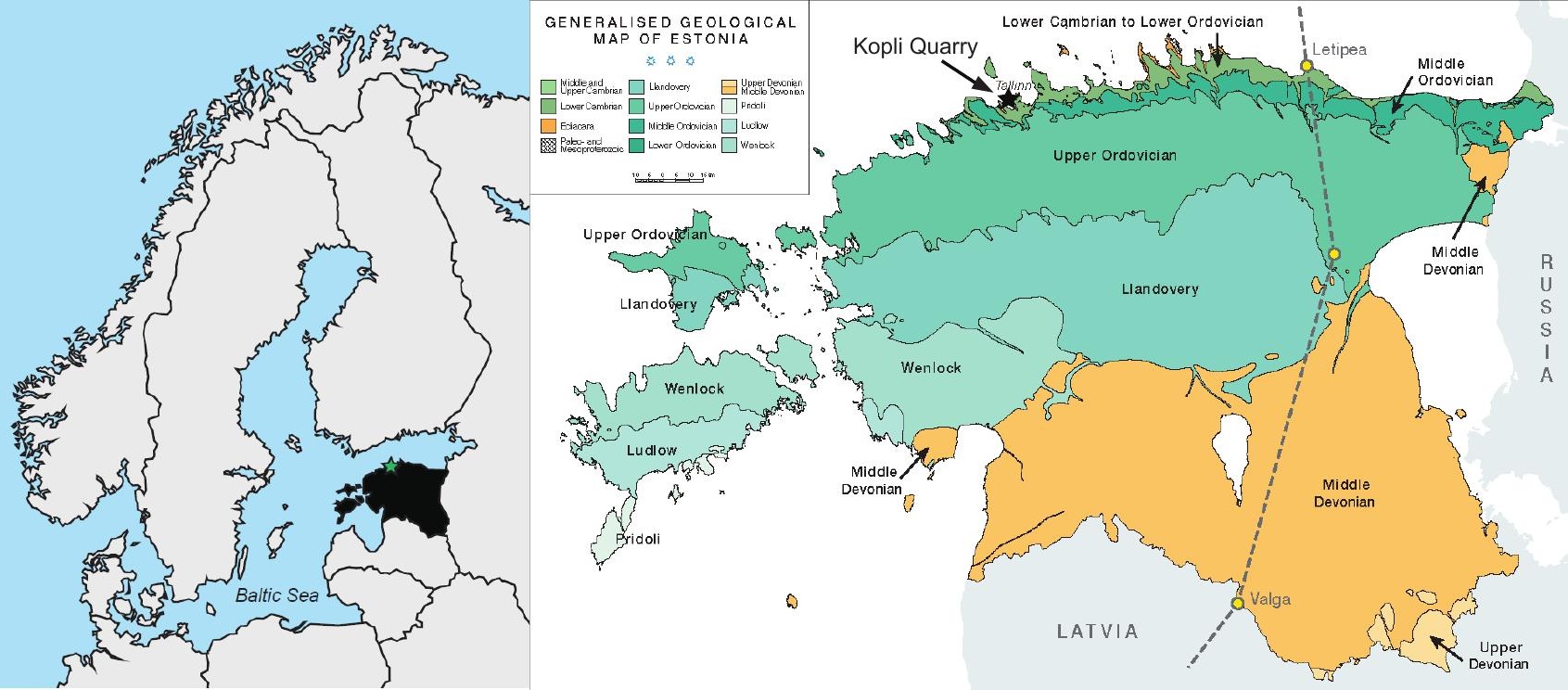




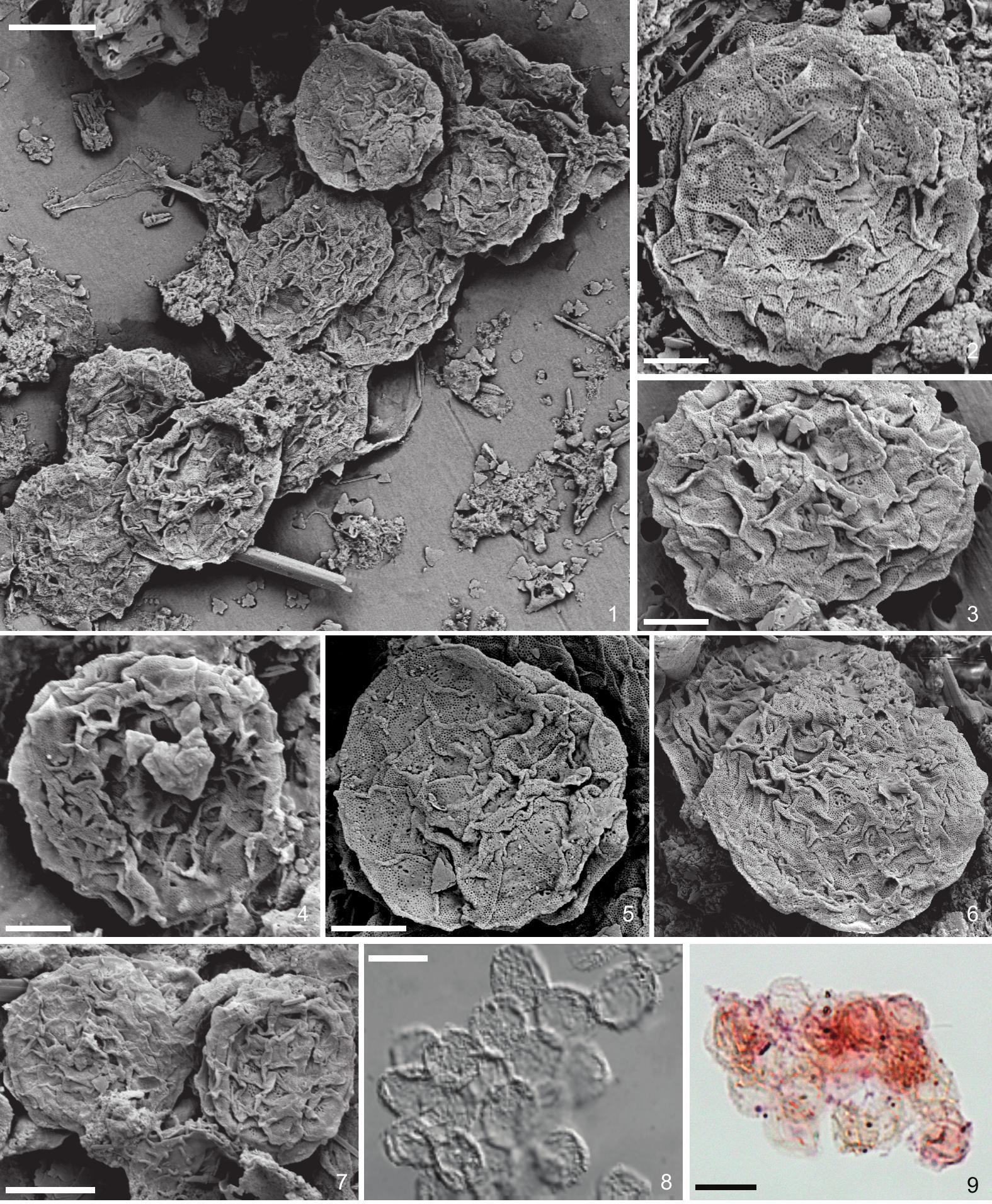



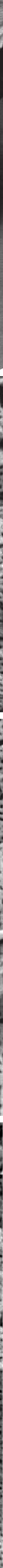


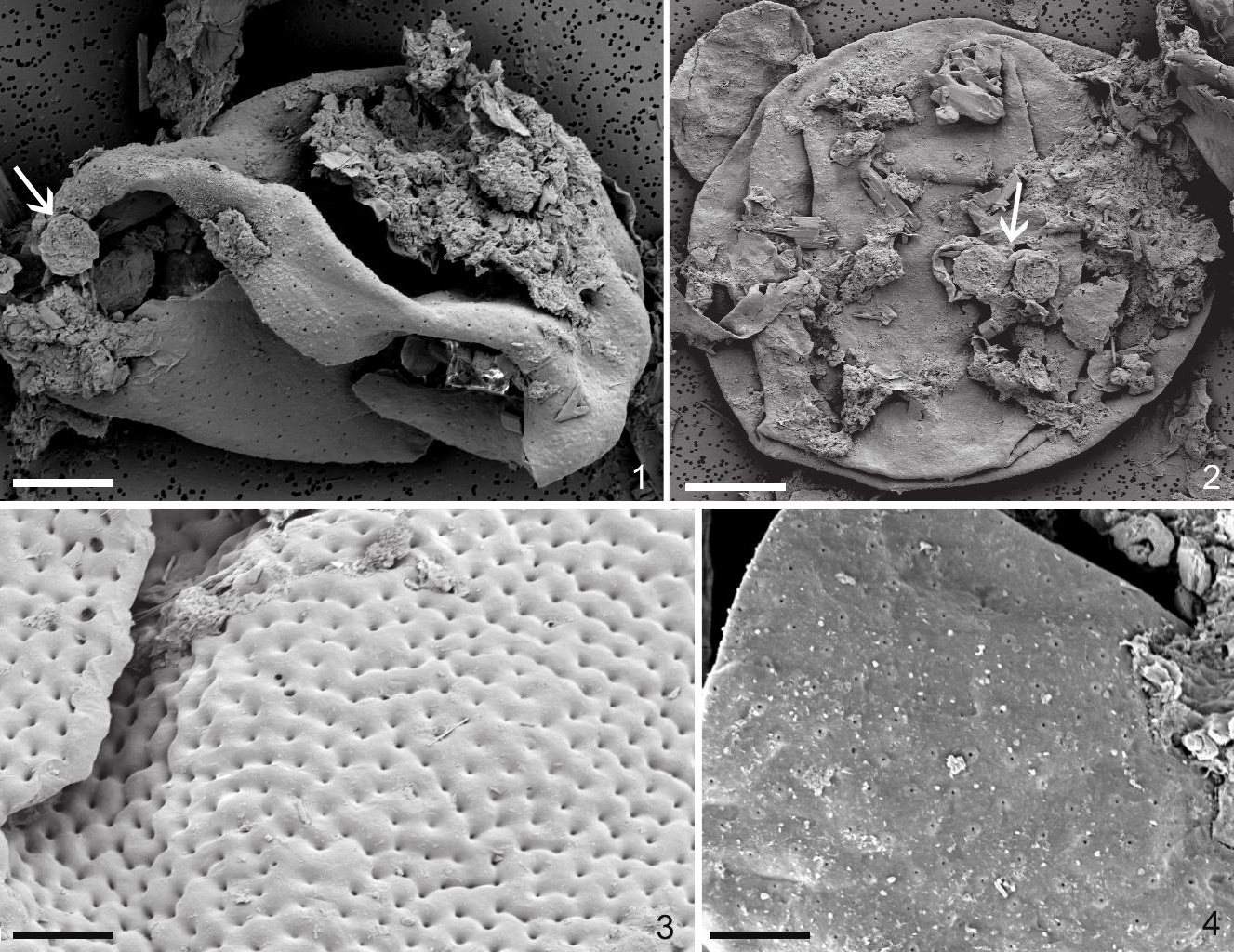




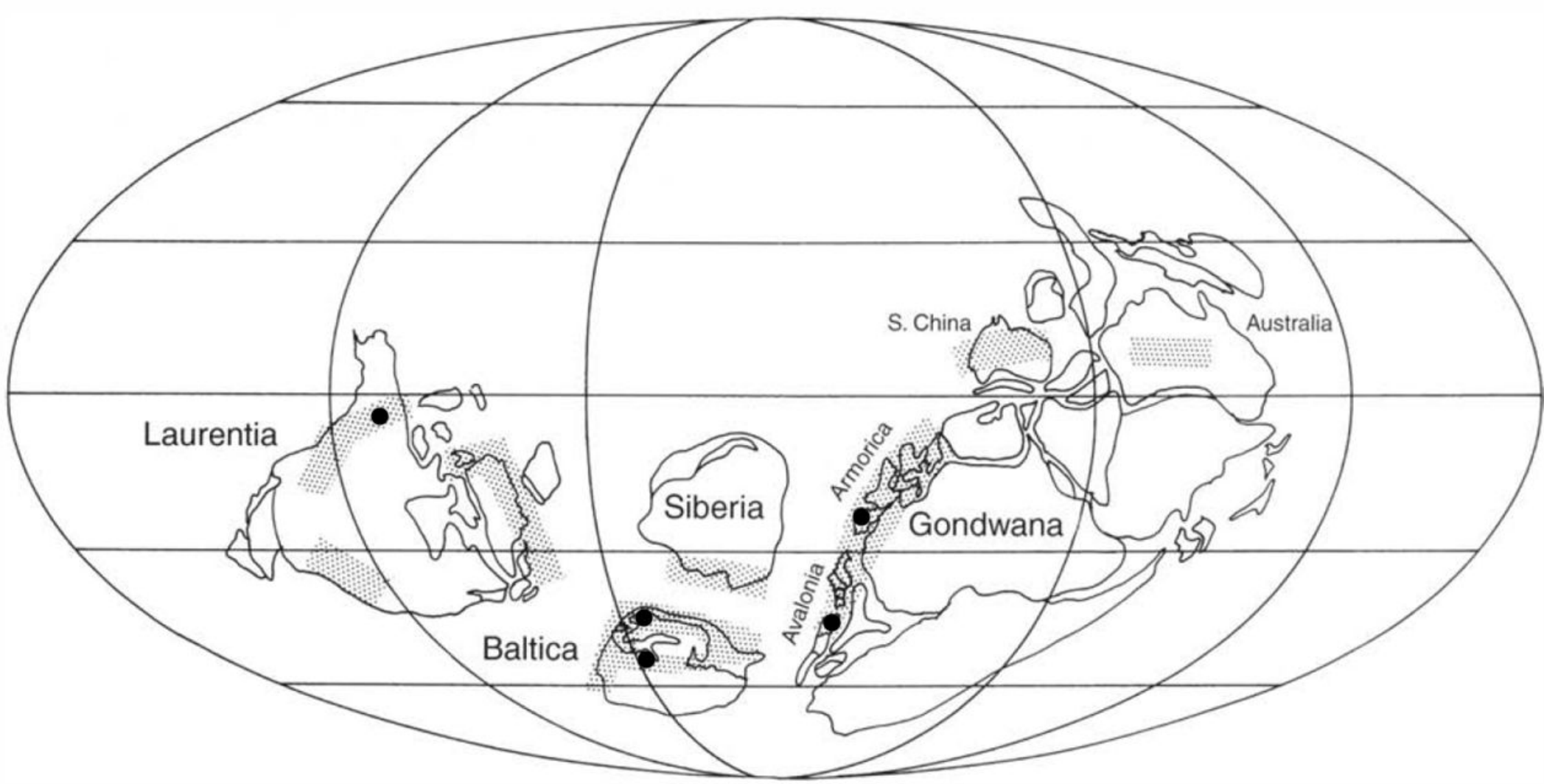

